DOI https://doi.org/10.30525/978-9934-26-184-8-10

\title{
СТВОРЕННЯ СТІЙКОГО ДО БУРОЇ ТА ЛИСТОВОЇ ІРЖІ ВИХІДНОГО МАТЕРІАЛУ ПШЕНИЦІ М'ЯКОЇ ОЗИМОЇ ШЛЯХОМ КУЛЬТУРИ ПИЛЯКІВ IN VITRO
}

\author{
Замбріборщ I.C. \\ кандидат біологічних наук, \\ завідувачка лабораторії культури тканин \\ Селекційно-генетичний інститут - Національний цеентр \\ насіннєзнавства та сортовивчення
}

Шестопал О. Л.

кандидат біологічних наук,

провідний наук. співробітник лабораторії культури тканин

Селекційно-генетичний інститут - Національний центтр насіннєзнавства та сортовивчення

м. Одеса, Україна

Найбільш радикальним, перспективним, екологічно безпечним та економічно вигідним напрямом удосконалення інтегрованої системи захисту озимої пшениці є вирощування сортів, стійких до шкідників і збудників хвороб. Саме цей напрям дає змогу без додаткових затрат звести до мінімуму втрати врожаю від шкідливих організмів і зменшити енерговитрати на 25-30\%, а також утворити нову екологічну нішу в агробіоценозах [1, с. 218]. Puccinia triticina Eriks. (Puccinia recondita Rob. ex Desm f.sp. tritici) $\epsilon$ одним із найбільш шкідливих захворювань пшениці. Збудник бурої іржі гетерогенний за вірулентністю та агресивністю. Нині в Україні ідентифіковано понад 200 рас, значну кількість біотипів.

Сьогодні рівень розробок та технологічних прийомів отримання лінійного матеріалу пшениці (андрогенез in vitro чи метод гаплопродюсера) знаходиться на високому рівні, що дозволяє використовувати даний метод, як невід'ємну частину селекційного процесу даної культури. Біотехнологічні методи дають можливість отримати нові форми пшениці, стійкі до різних 
несприятливих факторів, в максимально короткі терміни і без задіяння великих посівних площ $[2,4,6,7]$. Актуальним завданням дослідників $\epsilon$ розробка і оптимізація біотехнологічної методики, яка дозволить максимально швидко і ефективно отримувати стабільні форми стійких рослин пшениці. Мета дослідження - отримати дигаплоїдні лінії пшениці м'якої озимої шляхом гаплопродукційного процесу в культурі пиляків in vitro 3 метою створення нового вихідного селекційного матеріалу, стійкого до іржі.

Дослідний матеріал наданий відділом селекції та насінництва пшениці та відділом фітопатології СГІ-НЦНС. У роботу з отримання дигаплоїдних ліній пшениці озимої м'якої залучено 23 селекційних зразки різного походження, що вирізняються стійкістю до бурої та стеблової іржі. Рослини вирощували на польових ділянках СГІ-НЦНС. Пагони з пиляками зрізали 3 донорних рослин, коли мікроспори знаходились на вакуолізованій фазі розвитку (від ранньої до пізньої вакуолізації). Попередню обробку зрізаних пагонів проводили у водному розчині АБК (0,5 мг/л) протягом 3-5 діб при $+2-+4{ }^{\circ} \mathrm{C}$ у темряві. Колосся поверхнево стерилізували насиченим розчином гіпохлориту кальцію за прийнятою методикою. Ізольовані пиляки висаджували на індукційне живильне середовище 190-2 у модифікації [7]. Висаджені пиляки культивували перші 3 доби у темряві за температури $+30{ }^{\circ} \mathrm{C}$, далі - при $+24{ }^{\circ} \mathrm{C}$ до появи новоутворень. Сформовані макроструктури пересаджували на середовище MS у модифікації і культивували у темряві 10-14 діб, після чого пересаджували на живильне середовище MS 3 додаванням 0,5 мг/л ГК та 25 мг/л яблуневої кислоти та культивували перші 3-5 діб у термостаті, надалі 2-3 тижня при освітленні до появи центрів регенерації за умов 16-годинного фотоперіоду, інтенсивності освітлення -8 тис. люкс, температурі $+24{ }^{\circ} \mathrm{C}$ до формування рослин [7]. Зелені рослини адаптували до грунту та яровизували 45-50 діб за температури $+2-4{ }^{\circ} \mathrm{C}$, 16-годинному фотоперіоді, інтенсивності освітлення 500 - 1000 люкс. Надалі рослини-регенеранти дорощують в умовах штучного клімату до отримання насіння.

Залежність ефективності гаплопродукції в культурі пиляків м'якої пшениці від генотипу не дає змогу забезпечити 
передбачуваність результатів при роботі з будь-яким генотипом i підштовхує дослідників на пошуки можливої активації морфогенетичної компетентності в умовах in vitro [8-10]. Проводили гомозиготацію генотипів пшениці, стійких до бурої, стеблової та листової іржі Наданий дослідний матеріал вперше залучався в культуру пиляків, тобто мав невідому чутливість до андрогенезу in vitro.

Результати досліджень даного матеріалу різних генотипів пшениці озимої м'якої показали, що за даних умов експерименту, усі досліджені зразки виявились чутливими до першого етапу андрогенезу in vitro (формування новоутворень). Відсоток формування новоутворень від висаджених пиляків коливався від $0,31 \pm 0,31$ (лінія № 13/20) до 18,48 $\pm 2,23$ (гібрид № 13/20 / 132/20). Виявлено, що даний показник в культурі пиляків всіх досліджених зразків мав досить високі величини, а у шести (№o 3/20, 8/20, 120/20, 226/20, 132/20, 352/20) - на рівні генотипів озимої пшениці, що є донорами гаплопродукції.

Однак, на наступному етапі - регенерації рослин - зелені рослини-регенеранти отримали лише в культурі пиляків сімнадцяти 3 двадцяти трьох генотипів. Причому, новоутворення, отримані в культурі пиляків чотирьох батьківських ліній (№o 12/20, 13/20, 28/20, 154/20), не регенерували жодної зеленої рослини. Найгіршою гаплопродукційною здатністю характеризувалась лінія 28/20. Три гібриди, де остання була за материнський компонент, також не регенерували рослини за андрогенезу in vitro.

Всього в результаті дослідження отримано 150 зелених рослин-регенерантів. Відсоток виживаності після етапів адаптації до умов еx vitro та 45 добової яровизації склав 93,45 \%. Таким чином, на сьогодні, 129 регенерантів дорощуються у камері штучного клімату для отримання насіння.

\section{Література:}

1. Моргун В.В., Топчій Т.В. Значення стійких сортів озимої пшениці, вивчення джерел і донорів стійкості до шкідників та основних збудників хвороб. Физиология растений и генетика. 2018. T. 50. № 3. C. 218-240. doi: https://doi.org/10.15407/frg2018.03.218 
2. Tadesse W., Tawkaz S., Inagaki M.N., Picard E., and Baum M. Methods and Applications of Doubled Haploid Technology in Wheat Breeding.ICARDA, Aleppo, Syria. 2013. P. 3-6.

3. Broughton, S., Castello, M., Liu, L., Killen, J., Hepworth, A., O'Leary, R. The Effect of Caffeine and Trifluralin on Chromosome Doubling in Wheat Anther Culture. Plants. 2020. №9 (1). P. 105.

4. Ruwani D.M., Mayakaduwa G., Silva Tara D. Anther culture in rice: Progress and breeding perspective: Rice Crop - Current Developments. Ch.1. 2018. P. 1-15.

5. Шестопал О. Л., Замбріборщ I. С., Шпак Д. В., Алєксєєва Т. Г., Афіногенов О. А. Оцінка регенераційного потенціалу гібридного матеріалу рису посівного (Oryza sativa L.). Вісник ОНУ: Біологія. 2020. Т. 25, вип. 1(46). С. 88-96.

6. Замбриборщ И. С., Шестопал О. Л. Использование метода гаплоидии (андрогенез in vitro) в селекционном процессе злаковых культур Юга Украины. Биология клеток растений in vitro и биотехнология: тез. докладов XI межд. конф. (Минск, 23-27 сентября 2018 г.). Минск, 2018. С. 72-73.

7. Отримання подвоєних гаплоїдів м'якої пшениці в культурі пиляків: Методичні рекомендації / Ігнатова С.О., Жосонар М.В., Лобанова К.І. та ін.; Півден. біотехнолог. Центр в рослин-ві УААН. Одеса, 2008. 12 с.

8. Замбріборщ I.С., Шестопал О.Л., Бойко М.С. Генотипові особливості морфогенетичних реакції сортів і гібридів $\mathrm{F}_{1}$ пшениці озимої м'якої проходження різних етапів андрогенезу in vitro // Фактори експериментальної еволюції організмів: зб. наук. пр. К.: Укр. т-во генетиків і селекціонерів ім. М.І. Вавилова, 2018, T. 22. C. 252-256.

9. Testillano, P.S. Microspore embryogenesis: Targeting the determinant factors of stress-induced cell reprogramming for crop improvement // J. Exp. Bot. 2019, 70, P. 2965-2978.

10. Замбріборщ І.С., Шестопал О.Л., Чекалова М.С., Голуб Є.А. Тестування гаплопродукційної здатності різних гібридів пшениці м'якої в культурі пиляків in vitro // Фактори експериментальної еволюції організмів: зб. наук. пр. XV Міжн. наук. конф., К.: Укр. т-во генетиків і селекціонерів ім. М.І. Вавилова, 2020, Т. 26. С. 207-211. 